\title{
PERAN KESEIMBANGAN PEKERJAAN-KELUARGA DAN KUALITAS HIDUP TERHADAP KEBAHAGIAAN KERJA PADA PETUGAS PEMASYARAKATAN PEREMPUAN
}

\author{
Ika Zenita Ratnaningsih, Anggun Resdasari Prasetyo
}

\author{
Fakultas Psikologi Universitas Diponegoro \\ J1. Prof Soedarto, SH, Tembalang, Semarang, Jawa Tengah, Indonesia 50275 \\ ikazenita@live.undip.ac.id
}

\begin{abstract}
Correctional officers encounter vulnerable working conditions that may cause psychological discomfort at work. This study aims to determine the role of work-family balance, and quality of life to happiness at work in female correctional officers. The subjects in this study were 87 female correctional officers from three correctional institutions in Semarang and Malang. The age of subjects ranged from $22-57$ years $\left(M_{\text {age }}=41.80\right)$; and the work period of the subjects ranged from 3-34 years $\left(M_{\text {tenure }}=18.80\right)$. The sampling technique used was convenience sampling. Instruments that used for data collection were demographic data questionnaires, WorkFamily Balance Scale (32 items; $\alpha=.898$ ), WHOQOL-BREF Scale (26 items; $\alpha=.906$ ), and Happiness at Work Scale (22 items; $\alpha=.801)$. Data analysis using multiple regression analysis show there a positive and significant correlation between work-family balance and happiness at work $(r=.613 ; p<.001)$, there was a positive and significant correlation between quality of life and work happiness $(r=.394 ; p<.001)$, furthermore work-family balance and quality of life together can predict happiness at work in female correctional officers $(r$ $\left.=.633 ; R^{2}=.401 ; F=28.115 ; p<.001\right)$. Work-family balance and quality of life effectively contributed $39.7 \%$ to predicting happiness at work in female correctional officers.
\end{abstract}

Keywords: work-family balance; quality of life; happiness at work; female correctional officer

\begin{abstract}
Abstrak
Petugas pemasyarakatan rentan mengalami kondisi yang menimbulkan ketidakyamanan secara psikologis dalam bekerja. Penelitian ini bertujuan untuk mengetahui peran keseimbangan pekerjaan-keluarga dan kualitas hidup terhadap kebahagiaan kerja pada petugas lembaga pemasyarakatan perempuan. Subjek pada penelitian ini adalah 87 orang petugas pemasyarakatan berjenis kelamin perempuan dari tiga lembaga pemasyarakatan yang ada di Semarang dan Malang. Usia subjek berkisar antara $22-57$ tahun $\left(M_{\text {usia }}=41,80\right)$; dan masa kerja subjek berkisar antara 3-34 tahun $\left(M_{\text {masa kerja }}=18,80\right)$. Teknik sampling yang digunakan adalah convenience sampling. Metode pengumpulan data menggunakan kuesioner data demografi, Skala Keseimbangan Pekerjaan-Keluarga (32 item; $\alpha=0,898)$, Skala Kualitas Hidup WHOQOL-BREF (26 item; $\alpha=0,906)$, dan Skala Kebahagiaan Kerja (22 item; $\alpha=0,801$ ). Analisis data menggunakan analisis regresi berganda menunjukkan adanya korelasi positif signifikan antara keseimbangan kerja-keluarga dengan kebahagiaan kerja $(r=0,613 ; p<0,001)$, ada korelasi positif signifikan antara kualitas hidup dengan kebahagiaan kerja $(r=0,394 ; p<0,001)$, dan keseimbangan kerjakeluarga serta kualitas hidup secara bersama-sama dapat memprediksi kebahagiaan kerja pada petugas lapas perempuan $\left(r=0,633 ; R^{2}=0,401 ; F=28,115 ; p<0,001\right)$. Secara bersama-sama variabel keseimbangan pekerjaankeluarga dan kualitas hidup memberikan sumbangan efektif sebesar 39,7\% dalam memprediksi kebahagiaan kerja pada petugas pemasyarakatan wanita.
\end{abstract}

Kata kunci: keseimbangan pekerjaan-keluarga; kualitas hidup; kebahagiaan kerja; petugas lapas perempuan

\section{PENDAHULUAN}

Situasi yang rentan menimbulkan ketidakyamanan secara psikologis seperti timbulnya stres kerja dan burnout cenderung dialami oleh petugas pemasyarakatan dalam pekerjaannya (Keinan \& Malach-Pines, 2007). Hal tersebut juga terjadi pada petugas lembaga pemasyarakatan (lapas) di Indonesia (Prihatsanti, Ratnaningsih \& Prasetyo, 2013; Prihatsanti, Prasetyo \& Ratnaningsih, 2014). Penelitian tersebut 
menemukan bahwa sumber stres pada petugas pemasyarakatan diantaranya berasal dari ketakutan petugas akan ancaman fisik karena harus menjaga jumlah tahanan yang over kapasitas, munculnya kekhawatiran karena adanya kondisi chaos seperti perkelahian atau pelarian pada beberapa lapas di Indonesia, kurangnya dukungan rekan kerja dan manajemen, dan kurangnya jumlah petugas yang menyulitkan dalam melakukan koordinasi. Kondisi-kondisi tersebut mempengaruhi petugas pemasyarakatan baik secara fisik, psikologis maupun perilaku keseharian di tempat kerja.

Lebih lanjut Prihatsanti, Ratnaningsih dan Prasetyo (2017) menemukan bahwa petugas pemasyarakatan dengan jenis kelamin perempuan memiliki tingkat stres yang lebih tinggi daripada petugas pemasyarakatan lakilaki. Kaum perempuan ditengarai lebih sering mengalami gangguan kesehatan mental. Hal ini senada dengan apa yang dikemukakan oleh King (2008) dan Albert (2015), bahwa perempuan memiliki prevalensi yang lebih tinggi dari laki-laki untuk mengalami depresi. Mengingat rentannya kaum perempuan dengan stres yang dapat menyebabkan depresi, maka menjadi satu hal yang penting untuk memahami kondisi kerja pada kaum perempuan.

Penelitian pada petugas lembaga pemasyarakatan (correctional officer) pada kajian psikologi positif masih jarang dilakukan baik dalam skala nasional maupun internasional. Selama ini kajian tentang petugas pemasyarakatan lebih banyak dikaitkan dengan stress kerja (Dowden \& Tellier, 2004). Padahal bekerja sebagai salah satu tugas perkembangan bagi individu di masa dewasa memiliki bermacam makna bagi setiap orang. Wardani dan Sawitri (2015) menemukan bahwa pada petugas pemasyarakatan, apabila pekerjaan dimaknai sebagai sebuah panggilan (career calling) akan mendatangkan konsekuensi berupa kesejahteraan psikologis. Lebih lanjut Diener dan Biswas-Diener (2008) menjelaskan bahwa karyawan dengan calling orientation mencintai pekerjaan, menganggap bahwa pekerjaan adalah hal yang penting, dan memberikan kontribusi bagi organisasi serta melakukan pekerjaan karena mendapat penguatan intrinsik dari dalam dirinya. Hal itu menunjukkan adanya kebermaknaan dalam bekerja yang menjadikan individu merasa lebih puas dengan pekerjaannya (Keles \& Mine, 2016). Munculnya kepuasan dalam pekerjaan juga terkait dengan kepuasan individu dengan hidupnya secara umum (Filiz, 2014; Mafini \& Dlodlo, 2014). Lebih lanjut Diener (2007) menyatakan bahwa kepuasan dalam hidup merupakan bentuk nyata dari kebahagiaan.

Kebahagiaan adalah konstruk yang unik yang terdiri dari aspek kontekstual yang sangat kuat (Anggoro \& Widhiarso, 2010). Salah satu hal yang mempengaruhi kebahagiaan adalah kehidupan sosial (Seligman, 2005), lebih spesifik kehidupan sosial yang penting dalam mempengaruhi kebahagiaan adalah pekerjaan. Hal tersebut menjadikan kebahagian di tempat kerja menjadi lebih spesifik daripada kebahagiaan secara umum. Kebahagiaan kerja (happiness at work) dapat diidentifikasikan sebagai suatu pola pikir yang memungkinkan karyawan untuk memaksimalkan performa dan meraih potensi, yang dilakukan dengan menyadari tinggi rendahnya perasaan bahagia tersebut ketika bekerja, baik sendiri atau dengan karyawan lain (Pryce-Jones, 2010). Diener dan Biswas-Diener (2008) menjabarkan bahwa kebahagiaan kerja dapat dicirikan sebagai perasaan antusias terhadap pekerjaan, bersemangat untuk datang bekerja, memiliki hubungan yang baik dengan rekan kerja, menunjukkan saling ketergantungan dengan orang lain atau bidang lain di tempat kerja, memiliki performa kerja yang baik, dapat bergaul dengan karyawan lain, bersedia menggantikan jadwal kerja teman ketika dibutuhkan, bekerja pada beberapa proyek lain di luar deskripsi tugasnya yang bertujuan untuk meningkatkan performa tempat kerja, produk, dan pelayanannya 
terhadap pekerjaan. Oleh karena itu dapat disimpulkan bahwa kebahagiaan kerja merupakan suatu perasaan antusias yang dirasakan karyawan terhadap pekerjaannya sehingga memungkinkan karyawan untuk memaksimalkan performa dalam bekerja.

Dari hasil penelusuran mengenai penelitian yang bertujuan untuk mengungkap kebahagiaan pada setting pekerjaan, beberapa profesi yang telah diteliti diantaranya guru agama (Aziz, 2011), buruh gendong (Angriyani \& Hayati, 2014), karyawan dari sebuah perusahaan ritel (Sherlywati, 2015), dan pegawai universitas negeri (Wulandari \& Widyastuti, 2010). Dari sejumlah penelitian tentang kebahagiaan di tempat kerja, dapat diketahui bahwa prediktor yang membuat seseorang bahagia diantaranya adalah hubungan positif dengan orang lain, prestasi, lingkungan kerja fisik, kompensasi dan kesehatan (Wulandari \& Widyastuti, 2010), pengalaman spiritual (Aziz, 2011), perasaan yang baik terhadap diri, gembira, bangga, mudah bergaul, aktif (Csikszentmihalyi \& Hunter, 2003), hubungan, kualitas kehidupan kerja dan kepemimpinan (Chaiprasit \& Santidhiraku, 2011). Dari sejumlah penelitian tersebut, dapat disimpulkan bahwa kebahagiaan di tempat kerja muncul dari dalam diri dan karena adanya dukungan dari lingkungan terdekat.

Kebahagiaan di tempat kerja terbukti memberikan dampak kepada kesuksesan dan hasil kerja yang baik (Lyubomirsky, King, \& Diener, 2005; Boehm \& Lyubomirsky, 2008) sehingga hal tersebut menjadikan kebahagiaan kerja menjadi sesuatu yang penting untuk dikembangkan. Terlebih pada kancah lembaga pemasyarakatan, utamanya pada petugas pemasyarakatan perempuan yang memiliki beban ganda, yaitu beban sebagai pekerja dan beban sebagai ibu dan istri dalam keluarga.

Meningkatnya peran wanita sebagai pencari nafkah keluarga maupun sebagai ibu rumah tangga ternyata dapat menimbulkan konflik, karena kedua peran tersebut sama-sama membutuhkan waktu, tenaga dan perhatian. Hasil penelitian Keene dan Quadagno (2004) menjelaskan bahwa $60 \%$ orang dewasa yang bekerja sulit mencapai keseimbangan, terutama pasangan suami istri yang keduanya bekerja dengan anak di bawah 18 tahun. Menjalankan peran dalam keluarga dan pekerjaan memerlukan adanya keseimbangan pekerjaan-keluarga atau work-family balance.

Greenhaus, Collins, dan Shaw (2003), menjelaskan keseimbangan pekerjaankeluarga merupakan sejauh mana individu terlibat dan puas dengan peran dalam urusan pekerjaan dan keluarga. Hal itu terkait dengan pencapaian peran yang dilakukan individu sehubungan dengan harapan akan adanya negosiasi dan berbagi peran dalam domain pekerjaan dan keluarga. Hal itu penting karena keseimbangan dalam mengatur waktu untuk bersantai dan memulihkan kembali kondisi fisik akan menjaga kemampuan individu dalam menyelesaikan pekerjaan. Ketidakseimbangan antara pekerjaan dan keluarga akan menjadikan seseorang tidak dapat menikmati hidupnya dan akan merasa terbebani, kesulitan untuk bertemu dengan teman, keluarga, dan pasangan (Meenakshi, Subrahmanyam, \& Ravichandran 2013).

Terminologi keseimbangan pekerjaankeluarga digunakan untuk pekerja yang berstatus sebagai orang tua atau telah menikah yang menginginkan keseimbangan dalam pekerjaan dan keluarganya (Kalliath \& Brough, 2008). Marks dan MacDermind (1996) mengungkapkan bahwa konsep keseimbangan peran menawarkan suatu alternatif bahwa individu memprioritaskan peran secara hierarki untuk mengorganisir dan mengatur berbagai tanggungjawab. Greenhaus dkk. (2003) mengungkapkan bahwa komponen keseimbangan kerjakeluarga adalah time balance, involvement balance dan satisfaction balance. 
Hal yang juga mempengaruhi kebahagian kerja diantaranya adalah kondisi individu yang merupakan hasil dari interaksi faktor sosial, kesehatan, ekonomi, dan lingkungan yang dapat mempengaruhi kondisi sosial dan perkembangan manusia. Kondisi tersebut seringkali dikenal sebagai kualitas hidup. Carr dan Higginson (2001) mengumpulkan beberapa definisi kualitas hidup dan membuat kesimpulan bahwa kualitas hidup ditentukan oleh beberapa hal yaitu seberapa jauh kesesuaian antara harapan dan ambisi dengan pengalaman yang dicapai individu, persepsi individu mengenai posisi mereka dalam kehidupan dilihat dari konteks budaya dan sistem nilai dimana individu tinggal serta hubungannya dengan tujuan, harapan, standar, dan hal-hal lain yang menjadi perhatian individu tersebut, penilaian mengenai keadaan seseorang bila dibandingkan dengan kondisi ideal tertentu, hal-hal yang dianggap penting dalam kehidupan seseorang. Goodinson dan Singleton (dalam Wardhani, 2006) menyebutkan tiga faktor umum yang mempengaruhi kualitas hidup individu, yaitu keadaan lingkungan fisik, lingkungan sosial, dan lingkungan personal individu. Pengukuran terhadap kualitas hidup dapat dilakukan dengan melihat kondisi objektif dalam kehidupan individu.

Berdasarkan uraian di atas, peneliti bermaksud untuk meneliti peran keseimbangan pekerjaan-keluarga dan kualitas hidup dengan kebahagian kerja pada petugas pemasyarakatan perempuan. Tujuan penelitian ini adalah menguji secara empiris hubungan antara keseimbangan pekerjaankeluarga dan kualitas hidup dengan kebahagiaan kerja.

\section{METODE}

Subjek pada penelitian ini adalah Petugas Pemasayarakatan di Lapas Perempuan yang berjumlah 87 orang dari tiga lapas di Semarang dan Malang, teknik sampling yang digunakan adalah convenience sampling. Usia subjek berkisar antara 22 - 57 tahun
$\left(\mathrm{M}_{\text {usia }}=41,80\right)$, dan masa kerja subjek berkisar antara 3-34 tahun $\left(\mathrm{M}_{\text {masa kerja }}=\right.$ 18,80). Karakteristik subjek adalah berjenis kelamin perempuan, bertugas sebagai petugas pemasyarakatan dan telah menikah. Metode pengumpulan data menggunakan kuesioner data demografi, Skala Keseimbangan Pekerjaan-Keluarga (32 item, $\alpha=0,898$ ), Skala Kualitas Hidup WHOQOLBREF (26 item, $\alpha=0,906$ ), dan Skala Kebahagiaan Kerja (22 item, $\alpha=0,801$ ). Kuesioner data demografi disusun oleh peneliti bertujuan untuk mengetahui data pribadi subjek, yaitu usia, masa kerja dan lokasi kerja. Skala Keseimbangan PekerjaanKeluarga menggunakan skala yang disusun Novenia \& Ratnaningsih (2017) berdasarkan aspek Work-Family Balance yang dikemukakan oleh Greenhaus, Collins, dan Shaw (2003) yaitu time balance, involvement balance, dan satisfaction balance. Skala Keseimbangan Pekerjaan-Keluarga bertujuan untuk mengukur sejauh mana subjek merasakan keseimbangan antara peran dalam pekerjaan dan peran dalam keluarga. Skala Keseimbangan Pekerjaan-Keluarga berbentuk likert yang terdiri dari empat kategori jawaban, yaitu sangat sesuai (SS), sesuai (S), tidak sesuai (TS), dan sangat tidak sesuai (STS). Skala Kualitas Hidup menggunakan alat ukur WHOQOL-BREF yang merupakan pengembangan dari alat ukur WHOQOL-100 yang dibuat oleh WHO. Skala Kualitas Hidup bertujuan untuk mengukur kualitas hidup secara menyeluruh, meliputi dimensi fisik, kesejahteraan psikologis, hubungan sosial dan lingkungan. Skala Kualitas Hidup berbentuk likert dengan lima pilihan jawaban. Skala Kebahagiaan Kerja disusun berdasarkan indikator kebahagiaan dari Diener \& BiswasDiener (2008) yaitu karyawan menikmati pekerjaan, karyawan ingin berkontribusi terhadap pekerjaan, karyawaan merekomendasikan pekerjaan mereka, karyawan memikirkan pekerjaan, dan karyawan melakukan pekerjaan karena memperoleh reward dari pekerjaan tersebut. Skala Kebahagiaan Kerja berbentuk likert dengan lima pilihan jawaban yang bergerak 
dari pilihan Sangat Sesuai hingga Sangat Tidak Seseuai. Metode analisis data yang digunakan adalah teknik analisis regresi berganda, pengolahan data menggunakan bantuan program statistik SPSS.

\section{HASIL DAN PEMBAHASAN}

Berdasarkan hasil penelitian yang telah dilakukan, statistik deskriptif disajikan pada Tabel 1 .

Tabel 1.

Statistik Deskriptif

\begin{tabular}{llll}
\hline \multicolumn{1}{c}{ Variabel } & \multicolumn{2}{c}{ Skor Hipotetik } & Skor Empirik \\
& & & \\
\hline $\begin{array}{l}\text { Keseimbangan Kerja- } \\
\text { Keluarga }\end{array}$ & Minimum & 32 & 75 \\
& Maksimum & 128 & 127 \\
& Rerata & 80 & 99,75 \\
& SD & 16 & 9,59 \\
\hline Kualitas Hidup & Minimum & 26 & 67 \\
& & & \\
& Maksimum & 130 & 122 \\
& Rerata & 78 & 99,20 \\
& SD & 17,33 & 9,87 \\
\hline Kebahagiaan Kerja & Minimum & 22 & 68 \\
& & & \\
& Maksimum & 110 & 104 \\
& Rerata & 66 & 85,63 \\
& SD & 14,66 & 7,93 \\
\hline
\end{tabular}

Dari Tabel 1 nampak bahwa pada seluruh variabel, rerata empirik lebih tinggi dari rerata hipotetik. Hal ini menunjukkan bahwa keseimbangan kerja-keluarga, kualitas hidup dan kebahagiaan kerja berada pada kategori tinggi. Lebih lanjut dari hasil kategorisasi diketahui bahwa $65,6 \%$ subjek memiliki skor kebahagiaan kerja pada kategori tinggi, dan $34,4 \%$ berada pada kategori sangat tinggi. Diamati dari kategorisasi skor kualitas hidup, didapatkan $1,1 \%$ subjek memiliki kualitas hidup yang rendah, 65,6\% memiliki kualitas hidup yang tinggi, dan 33,3\% memiliki kualitas hidup yang sangat tinggi. Sementara itu $1,1 \%$ subjek memiliki tingkat keseimbangan pekerjaan-keluarga yang rendah, 64,5\% tinggi, dan 34,4\% memiliki tingkat keseimbangan pekerjaan-keluarga yang sangat tinggi. Adanya kesamaan lingkungan kerja dimungkinkan menjadikan hasil variasi yang didapatkan dari respon subjek memiliki kemiripan.

Dari hasil perhitungan didapatkan bahwa ada korelasi yang positif dan signifikan antara keseimbangan kerja-keluarga dengan kebahagiaan kerja $(r=0,613 ; \quad p=0,000$; $p<0,001)$. Demikian pula ada korelasi yang positif dan signifikan antara antara kualitas hidup dengan kebahagiaan kerja $(r=0,394$; $p=0,000 ; p<0,001)$, serta secara bersamasama ada korelasi yang positif dan signifikan antara keseimbangan kerja-keluarga dan kualitas hidup dengan kebahagiaan kerja $(r=0,633 ; p=0,000 ; p<0,001) ; R^{2}=0,401 ; F$ $=28,115 ; \quad p=0,000 ; \quad p<0,001 \quad$ sumbangan efektifnya sebesar $40,1 \%$. Ketiga hasil tersebut mendukung hipotesis dalam penelitian. Dari ketiga variabel yang menjadi prediktor tersebut, Nampak bahwa variabel 
keseimbangan pekerjaan-keluarga adalah variabel prediktor yang memiliki korelasi paling kuat. Selengkapnya ditampilkan dalam Tabel 2.

\section{Tabel 2.}

Hasil Bi-korelasi antar Variabel

\begin{tabular}{|c|c|c|c|c|c|}
\hline Variabel & $\begin{array}{c}\text { Rer } \\
\text { ata }\end{array}$ & $\begin{array}{l}\text { S } \\
\mathbf{D}\end{array}$ & 1 & 2 & 3 \\
\hline Kebahagi & 85,6 & 7 & 1 & 0,61 & 0,39 \\
\hline aan Kerja & 3 & 93 & & $3 * *$ & $4 * *$ \\
\hline Keseimba & 99,7 & 9, & 0,61 & 1 & 0,40 \\
\hline ngan & 5 & 59 & $3 * *$ & & $9 * *$ \\
\hline
\end{tabular}

Kerja-

Keluarga

Kualitas $\quad 99,2 \quad 9, \quad 0,39 \quad 0,40 \quad 1$

$\begin{array}{lllll}\text { Hidup } & 0 & 87 & 4 * * & 9 * *\end{array}$

**) Korelasi signifikan pada level 0,01

*) Korelasi signifikan pada level 0,05

Dari hasil analisis regresi terdapat sebuah model yang dapat dibuat dari hasil analisis, yaitu $\mathrm{Y}^{\prime}=27,073+0,449 \mathrm{X}_{1}+0,139 \mathrm{X}_{2}$ dengan $Y^{\prime}$ merupakan kebahagiaan kerja, $X_{1}$ keseimbangan pekerjaan-keluarga, dan $\mathrm{X}_{2}$ kualitas hidup.

Dari Tabel 2 dan model tersebut terlihat bahwa keseimbangan kehidupan keluarga memberi sumbangan efektif sebanyak 44,9\% dan kualitas hidup memberi sumbangan efektif sebanyak 13,9\% dalam memprediksi kebahagiaan kerja.

Dari hasil analisis regresi diketahui bahwa variabel prediktor yang dapat meramalkan kebahagiaan kerja adalah variabel keseimbangan keluarga-pekerjaan dan kualitas hidup. Sumbangan efektif keduanya adalah 40,1\% kepada kebahagiaan kerja. Hal tersebut menunjukkan bahwa ada hal-hal lain selain kedua variabel tersebut untuk memunculkan kebahagiaan kerja, misalnya Wulandari dan Widyastuti (2010) menyebutkan bahwa hubungan positif dengan orang lain, prestasi, lingkungan kerja fisik, serta kompensasi dan kesehatan membuat seseorang bahagia. Aziz (2011) juga menyebutkan bahwa pengalaman spiritual memiliki hubungan dengan kebahagiaan.
Penelitian lain menunjukkan bahwa dukungan sosial berhubungan dengan kebahagiaan kerja (Nurhidayah \& Agustini, 2012). Dari beberapa literatur mengenai faktor-faktor yang mempengaruhi kebahagiaan kerja, dapat disimpulkan bahwa terdapat faktor internal dan eksternal yang mempengaruhi kebahagiaan kerja. Faktor internal berkaitan dengan faktor yang berasal dari diri individu, sementara faktor eksternal berkaitan dengan faktor yang berasal dari organisasi. Faktor dari dalam diri individu diantaranya terkait dengan penemuan makna dalam keseharian yang menyangkut spiritualitas. Sementara faktor dari luar diri individu berasal dari organisasi yaitu relasi yang baik dengan orang lain (rekan kerja dan pimpinan), adanya sistem pengembangan karir yang jelas, dan keterlibatan penuh dalam pekerjaan (Prasetyo, 2015).

Secara empiris, keseimbangan keluarga dan pekerjaan serta kualitas hidupmerupakan prediktor yang dapat memprediksi kebahagiaan kerja. Hal ini sejalan dengan beberapa studi yang telah dilakukan sebelumnya yang menemukan bahwa kebahagiaan pada laki-laki dewasa di Taiwan dipengaruhi oleh kualitas hidup (Wu \& Tsay, 2016). Selain itu penelitian Nurendra dan Saraswati (2016) menjelaskan adanya peran work life balance terhadap kepuasan kerja pada karyawan.

Tercapainya keseimbangan kerja-keluarga menjadikan adanya kepuasan dalam diri subjek menyangkut keseimbangan waktu, keseimbangan keterlibatan, dan keseimbangan perilaku. Adanya kualitas hidup yang tinggi juga menandakan bahwa adanya kesejahteraan secara psikologis pada diri subjek. Terkait dengan subjek penelitian di lembaga pemasyarakatan, subjek mayoritas berada pada kategori tinggi dan sangat tinggi pada variabel keseimbangan kerja-keluarga, kualitas hidup dan kebahagiaan kerja. Hal tersebut diduga terkait dengan karakteristik organisasi yang memberikan keleluasaan pada petugas wanita dalam mengatur waktu untuk keluarga dan pekerjaan. Untuk 
mencapai hal tersebut lembaga pemasyarakatan dapat memberikan iklim yang suportif untuk menciptakan terciptanya keseimbangan pekerjaan-keluarga bagi para petugas lembaga pemasyarakatan perempuan yang memiliki beban ganda dalam pekerjaan dan dalam keluarga.

\section{SIMPULAN}

Ada hubungan antara variabel keseimbangan pekerjaan-keluarga, kualitas hidup dan kebahagiaan kerja pada petugas pemasyarakatan perempuan $\quad(r=0,633$; $p=0,000 ; p<0,001)$. Secara bersama-sama variabel keseimbangan pekerjaan-keluarga dan kualitas hidup memberikan sumbangan efektif sebesar $40,1 \%$ dalam memprediksi kebahagiaan kerja.

\section{DAFTAR PUSTAKA}

Albert, P. R. (2015). Why depression more prevalent in women?. Journal of Psychiatry \& Neuroscience, 40(4), 219221, doi: 10.1503/jpn.15020115

Anggoro, W. J., \& Widhiarso, W. (2010). Konstruksi dan identifikasi properti psikometris instrumen pengukuran kebahagiaan berbasis pendekatan indigenous psychology: Studi multitraitmultimethod. Jurnal Psikologi, 37(2), 176-188.

Angriyani, T. Y., \& Hayati, E. N. (2014). Kebahagiaan pada buruh gendong. Empathy, 2(2), 66-70.

Aziz, R. (2011). Pengalaman spiritual dan kebahagiaan pada guru agama sekolah dasar. Proyeksi, 6(2), 1-11.

Boehm, J. K., \& Lyubomirsky, S. (2008). Does happiness promote career success?. Journal of Career Assessment, 16(1), 101-116. doi:10.1177/1069072707308140
Carr, A. J., \& Higginson, I. J. (2001). Measuring quality of life: Are quality of. life measures patient centred?. BMJ, 322, p. 1357-1360.

Chaiprasit, K., \& Santidhiraku, O. (2011). Happiness at work of employees in small and medium-sized enterprises, Thailand. Procedia - Social and Behavioral Sciences, 25, 189-200. doi:10.1016/j.sbspro.2011.10.540

Csikszentmihalyi, M., \& Hunter, J. (2003). Happiness in everyday life: The uses of experience sampling. Journal of Happiness Studies, 4(January), 185199. doi:10.1023/A:1024409732742

Diener, E., \& Biswas-Diener, R. (2008). The science of optimal happiness. Boston: Blackwell Publishing.

Dowden, C., \& Tellier, C. (2004). Predicting work-related stress in correctional officers: A meta-analysis. Journal of Criminal Justice, 32(1), 31-47. doi:10.1016/j.jcrimjus.2003.10.003

Filiz, Z. (2014). An analysis of the level of job satisfaction and life satisfaction of the academic staff. Social Indicator Research, 116(3)

Greenhaus, J. H., Collins, K. H., \& Shaw, J. D. (2003). The relation between workfamily balance and quality of life. Journal of Vocational Behavior, 63, 510-531.

Kalliath, T., \& Brough, P. (2008). Work life balance: A review of the meaning of the balance construct. Journal of Management \& Organization, 14, 323327.

Keene, J. R., \& Quadagno, J. (2004). Predictors of perceived work-family balance: Gender difference or gender similarity?. Sociological Perspectives, 47(1), 1-24. 
Keinan, G., \& Malach-Pines, A. (2007). Stress and burnout among prison personnel: Souces, outcomes, and intervention strategies. Criminal Justice and Behavior, 34(1), 380-397

King, A. L. (2008). The science of psychology. An appreciative view. New York: The McGraw-Hill Companies, Inc.

Lyubomirsky, S., King, L., \& Diener, E. (2005). The benefits of frequent positive affect: Does happiness lead to success? Psychological Bulletin, 131(6), 803-855. doi:10.1037/00332909.131.6.803

Mafini, C., \& Dlodlo, N. (2014). The relationship between extrinsic motivation, job satisfaction and life satisfaction amongst employees in a public organisation. SA Journal of Industrial Psychology/SA Tydskrif vir Bedryfsielkunde, 40(1).doi: 10.4102/sajip.v40i1.1166

Marks, S. R., \& MacDermid, S. M. (1996). Multiple roles and the self: A theory of role balance. Journal of Marriage and the Family, 58, 417-432.

Meenakshi, P. S., Subrahmanyam, V., \& Ravichandran, K. (2013). The importance of work-life-balance. Journal of Business and Management, 4(3), 31-35.

Novenia, D. \& Ratnaningsih, I. Z. (2017). Hubungan antara dukungan sosial suami dengan work-family balance pada guru wanita di SMA Negeri Kabupaten Purworejo. Empati, 6(1), 97-103

Nurhidayah, S., \& Agustini, R. (2012). Kebahagiaan lansia ditinjau dari dukungan sosial dan spiritualitas. Jurnal Soul, 5(2), 15-32.
Prasetyo, A. R. (2015). Gambaran career happiness plan pada dosen. Jurnal Psikologi Undip 14(2), 174-182

Prihatsanti, U., Ratnaningsih, I. Z., \& Pasetyo, A. R. (2013). Menurunkan stres kerja petugas pemasyarakatan melalui teknik COPE. Jurnal Psikologi 40(2), 159-168

Prihatsanti, U., Prasetyo, A. R., \& Ratnaningsih, I. Z. (2014). Efektivitas pelatihan teknik cope sebagai salah satu alternatif problem focused coping untuk menurunkan stres kerja sipir lembaga pemasyarakatan. Laporan Penelitian Tidak Dipublikasikan. Semarang. Universitas Diponegoro

Prihatsanti, U., Ratnaningsih, I. Z., \& Prasetyo, A. R. (2017). Is there any differences of job stress among correctional officers based on gender in Java?. Journal of Educational, Health and Community Psychology, 6(1), 11-17

Pryces-jones. (2010). Maximizing your psychological capital for success. United Kingdom: A John Wiley \& Sons, Ltd., Publication.

Seligman, M. E. P. (2002). Authentic happiness: Using the new positive psychology to realize your potential for lasting fulfillment. New York: Free Press.

Seligman, M. E. P. (2005). Menciptakan kebahagiaan dengan psikologi positif (authentic happiness). Bandung: PT. Mizan Pustaka.

Wardani, A. A., \& Sawitri, D. R. (2015). Career calling dan psychological wellbeing pada petugas di lembaga pemasyarakatan klas 1 Semarang. Empati, 4(1), 28-34 
Wardhani, V. (2006). Gambaran kualitas hidup dewasa muda berstatus lajang melalui adaptasi instrumen WHOQOLBREF dan SRPB. Thesis. Depok: Pascasarjana Fakultas Psikologi Universitas Indonesia.
Wulandari, S., \& Widyastuti, A. (2010). Faktor - faktor kebahagiaan di tempat kerja. Jurnal Psikologi, 10(1), 49-60. 